\title{
Epidural anesthesia in Eira barbara Linnaeus, 1758 (Carnivora: Mustelidae).
}

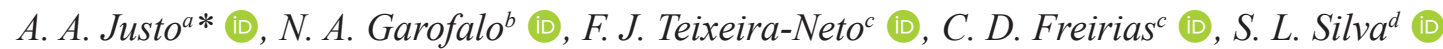 \\ and R. H. Pinho ${ }^{d}$ (D)
}

\begin{abstract}
a'Departamento de Cirurgia, Faculdade de Medicina Veterinária e Zootecnia, Universidade de São Paulo - USP, Rua Prof. Dr. Orlando Marques de Paiva, 87, Cidade Universitária, CEP 05508-270, São Paulo, SP, Brasil

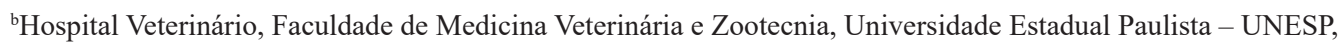
Rua Prof. Dr. Walter Mauricio Correa, s/n, Rubião Junior, CEP 18618-681, Botucatu, SP, Brasil

'Departamento de Cirurgia Veterinária e Reprodução Animal, Faculdade de Medicina Veterinária e Zootecnia, Universidade Estadual Paulista - UNESP, Rua Prof. Dr. Walter Mauricio Correa, s/n, Rubião Junior, CEP 18618-681, Botucatu, SP, Brasil

dDepartamento de Anestesiologia, Faculdade de Medicina de Botucatu, Universidade Estadual Paulista - UNESP, Rua Prof. Mário Rubens Guimarães Montenegro, s/n, Rubião Junior, CEP 18618-687, Botucatu, SP, Brasil

*email: andre.justo7@gmail.com
\end{abstract}

Received: July 11, 2019 - Accepted: November 28, 2019 - Distributed: May 31, 2021

(With 1 figure)

The tayra (Eira Barbara, Linnaeus 1758) is a wild carnivore belonging to the Mustelidae Family and deemed of least concern as a threatened species (Cuarón et al., 2016). Even though injectable protocols in tayras are found in the scientific database (Renner et al., 1998; Koproski et al., 2009), no reports were found concerning general anesthesia or regional anesthetic techniques for major procedures.

Pain perception requires a whole chain of mechanisms from peripheral nociceptors to the cerebral cortex. The simultaneous use of different drug classes and routes that modify distinct points in pain pathways is the basis of multimodal analgesia, contributing to synergistic analgesic effects and preventing high dosages of single agents, which could result in potential adverse effects (Lamont, 2008). Therefore, epidural anesthesia combined with anti-inflammatory drugs and systemic opioids augment patient comfort and minimize anesthesia morbidity. Considering the lack of information regarding the effectiveness of anesthetic techniques in free-ranging species, successful anesthetic managements should encourage further studies for the purpose of wildlife conservation.

An adult, $6.3 \mathrm{~kg}$, intact, male tayra was found prostrate, presumably after a vehicular accident, and was referred to the Center of Medicine and Research in Wild Animals (CEMPAS) at the São Paulo State University (Unesp), School of Veterinary Medicine and Animal Science, Campus Botucatu, for further evaluation. Radiographic imaging enlightened a complete, diaphyseal simple fracture in the proximal third of the left femur, which required a surgical procedure.

Recent studies focused on the tayra's vertebro-medullary topography, though there are controversies in regard to the exact spinal chord end, suggesting it to be either at the level of the fifth lumbar vertebra (L5) (Adami et al., 2015) or between L4 - L6 (Branco et al., 2013). For this reason, the epidural anesthesia was performed at the lumbosacral space (LSS), differently from what was recommended by other authors (Branco et al., 2013). Besides, the LSS in this tayra was as easily palpated as it is in dogs after proper body positioning in sternal recumbency with the hindlimbs moved forward, enhancing the odds for a successful epidural administration (Figure 1). The technique was performed with a 22-gauge catheter and its correct placement in the LSS was confirmed by the "hanging drop" technique (Valverde, 2008). Lidocaine (4 mg/kg) and morphine $(0.1 \mathrm{mg} / \mathrm{kg})$ were administered at this site, for a total volume of $0.2 \mathrm{~mL} / \mathrm{kg}$. For additional analgesia, intramuscular methadone $(0.2 \mathrm{mg} / \mathrm{kg})$ was also administered 30 minutes after the onset of surgery, as well as $0.2 \mathrm{mg} / \mathrm{kg}$ of subcutaneous meloxicam.

Anesthesia was maintained with isoflurane diluted in 1.0 inspired oxygen fraction after $1 \mathrm{mg} / \mathrm{kg}$ of intravenous propofol. A multiparametric monitor (LW9x ${ }^{\circledR}$, Digicare, Boynton Beach, Florida 33426, USA) was used for cardiorespiratory monitoring. A pulse oximeter was disposed to the tongue to register peripheral oxygen saturation of hemoglobin $\left(\mathrm{SpO}_{2}\right)$ and skin ECG electrodes were placed according to a lead II configuration to monitor heart rate and rhythm. A multi-gas analyzer was connected to the Y-piece circuit for continuous measurement of end-tidal isoflurane concentrations $\left(\mathrm{ET}_{\mathrm{ISO}}\right)$ and end-tidal $\mathrm{CO}_{2}\left(\mathrm{ETCO}_{2}\right)$. The animal underwent intermittent positive-pressure ventilation (Fuji Maximus ${ }^{\circledR}, \mathrm{KTK}$, Sao Paulo, SP, 04257-100, Brazil) with tidal volume set at $10 \mathrm{~mL} / \mathrm{kg}$ and respiratory rate $(f)$ adjusted to maintain the $\mathrm{ETCO}_{2}$ ranging between $35-45 \mathrm{mmHg}$. An esophageal thermometer recorded core body temperature, which was held above $37{ }^{\circ} \mathrm{C}$ by means of an electric heating pad. The femoral artery was aseptically catheterized with a 22-gauge catheter for invasive systolic, diastolic and mean arterial blood pressure monitoring (SAP, DAP and MAP, respectively). The catheter was connected to a noncompliant pressure transducer system (TruWavePX260 ${ }^{\circledR}$, Edwards 


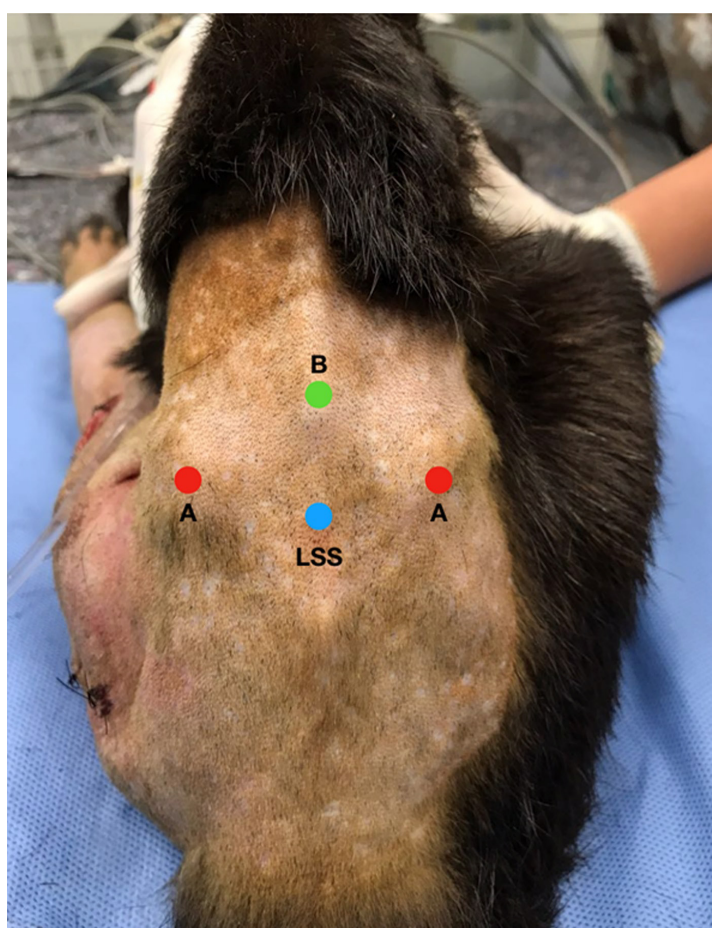

Figure 1. Anatomical landmarks for epidural anesthesia in tayras. A: Iliac crests; B: Spinous process of L6; LSS: Lumbosacral space.

Lifesciences, Irvine, California 92614, USA) fulfilled with heparinized saline solution $(5 \mathrm{IU} / \mathrm{mL}$ of heparinized physiological saline). The vaporizer dial was adjusted to achieve a surgical plane of anesthesia and $5 \mathrm{~mL} / \mathrm{kg} / \mathrm{h}$ of a lactated Ringer's solution was calculated as maintenance fluid therapy.

Heart rate varied between $100-115$ beats/min and the $f$ from 8 to 12 breaths $/ \mathrm{min}$. SAP, DAP and MAP values ranged between $60-100,40-60$ and $50-70 \mathrm{mmHg}$, respectively. The vaporizer dial setting oscillated from 0.9 to $1.3 \%$, leading to $\mathrm{ET}_{\mathrm{ISO}}$ concentrations between $0.8-1.2 \%$. By the end of surgery, the patient was allowed to recover at an isolated enclosure, which happened to be uneventful.

Epidural anesthesia provides intra and postoperative analgesia (McMurphy, 1993), being the latter a reasonable feature for wildlife, once it is often difficult to manage pain when animals are back to full consciousness. Lidocaine $2 \%$ without epinephrine, but not bupivacaine, was elected to be epidurally administered for its shorter duration of action (one to two hours) against up to four hours for bupivacaine (Valverde, 2008), considering that surgery was predicted to last no longer than an hour. Lidocaine's short period of action enabled the tayra to move the hindlimbs earlier following extubation. Additionally, epidural morphine was administered to contribute to postoperative analgesia since its analgesic effects may last for up to 24 hours (Steagall et al., 2017), as previously described in domestic species.
The minimum alveolar concentration of isoflurane in tayras is unknown, though low $\mathrm{ET}_{\text {ISO }}$ and cardiovascular stability suggested that epidural provided transoperative analgesia and possibly significant isoflurane-sparing effects. Low isoflurane requirements may have mitigated its inherent cardiovascular depressant effects and reduced anesthesia-related morbidities. Multimodal analgesia provided a better control of pain for both trans and postoperative periods, resulting in analgesia and cardiovascular stability throughout the procedure. Lumbosacral epidural anesthesia demonstrated to be a feasible and effective technique in Eira barbara.

\section{References}

ADAMI, M., REKOWSKY, B.S.S., SILVA, R.D.G., FARIA, M.M.M.D., PINTO, M.G.F. and ALMEIDA, A.E.F.S., 2015. Topografia vertebromedular de irara (Eira barbara Linnaeus, 1758). Pesquisa Veterinária Brasileira, vol. 35, no. 10, pp. 871874. http://dx.doi.org/10.1590/S0100-736X2015001000009.

BRANCO, E., LINS, F.L.M.L., PEREIRA, L.C. and LIMA, A.R., 2013. Topografia do cone medular da irara (Eira barbara) e sua relevância em anestesias epidurais. Pesquisa Veterinária Brasileira, vol. 33, no. 6, pp. 813-816. http://dx.doi.org/10.1590/ S0100-736X2013000600020.

CUARÓN, A.D., REID, F., HELGEN, K. and GONZÁLEZ-MAYA, J.F., 2016 [viewed 10 July 2019]. Eira barbara. The IUCN Red List of Threatened Species. Version 2019-1 [online] Cambridge: IUCN Available from: www.iucnredlist.org

KOPROSKI, L., NETO, G.G., MORAES, W. and PACHALY, J.R., 2009. Contenção farmacológica da irara (eira barbara linnaeus, 1758) pela associação de tiletamina, zolazepam, xilazina e atropina. Medvep, vol. 7, no. 21, pp. 238-242.

LAMONT, L.A., 2008. Multimodal pain management in veterinary medicine: The physiologic basis of pharmacologic therapies. The Veterinary Clinics of North America. Small Animal Practice, vol. 38, no. 6, pp. 1173-1186, v. http://dx.doi.org/10.1016/j. cvsm.2008.06.005. PMid:18954679.

MCMURPHY, R.M., 1993. Postoperative epidural analgesia. The Veterinary Clinics of North America. Small Animal Practice, vol. 23, no. 4, pp. 703-716. http://dx.doi.org/10.1016/S01955616(93)50077-3. PMid:8337785.

RENNER, M.S., BRYANT, W. and KENNEDY, G.A., 1998. Fibrocartilaginous Emboli in a Tayra (Eira barbara): A case report. Journal of Zoo and Wildlife Medicine, vol. 29, no. 4, pp. 470-473. PMid:10065859.

STEAGALL, P.V.M., SIMON, B.T., TEIXEIRA-NETO, F.J. and LUNA, S.P.L., 2017. An update on drugs used for Lumbosacral Epidural anesthesia and analgesia in dogs. Frontiers in Veterinary Science, vol. 68, no. 4, pp. 1-12. http://dx.doi.org/10.3389/ fvets.2017.00068. PMid:28553642.

VALVERDE, A., 2008. Epidural analgesia and anesthesia in dogs and cats. The Veterinary Clinics of North America. Small Animal Practice, vol. 38, no. 6, pp. 1205-1230. http://dx.doi.org/10.1016/j. cvsm.2008.06.004. PMid:18954681. 